\title{
The Sense of "Homeless" in the Early Short Works of Nathaniel Hawthorne
}

\author{
Mei Xiaohan*
}

M.A. in Department of Chinese, Fu Dan University, Shanghai, China

Corresponding Author: Mei Xiaohan, E-mail: Hawakefield@outlook.com

\section{ARTICLE INFO}

Article history

Received: January 11, 2019

Accepted: March 26, 2019

Published: April 30, 2019

Volume: 7 Issue: 2

Conflicts of interest: None

Funding: None

\section{Keywords: \\ Hawthorne, \\ Homelessness, \\ Nostalgia, \\ Uncanniness, \\ Ramble}

\begin{abstract}
In Nathaniel Hawthorne' s early literary works, "homelessness" was an important concept. It was not only reflected in the conflictions between the individuals and their house and clans, but also in Hawthorne's unique understanding of the concept of "home", which closely combined with various other concepts such as "Family" and "Homeland". Therefore, the sense of "homeless" cannot be simply understood as people leaving their family and homeland in space, or people losing their house in their real life, but also should be considered from the angle of religion, philosophy and the early American history. This article is based on complicated descriptions and representations of the sense of "homelessness" in Hawthorne' s early short works, and intends to show that "homelessness" is not only related to personal destiny and life choice, but also showed the ubiquity of people's "Being", the core concepts of understanding Hawthorne' $s$ creation.
\end{abstract}

\section{SENSE OF "UNCANNINESS": THE KEY CONCEPT IN HAWTHORNE' S EARLY WORKS}

In the early works of Nathaniel Hawthorne, the discussion about "home" in Hawthorne' s early short novels was always the crucial clue to understand his works. During this phase, Hawthorne' s creation usually embroidered on the concept of "home" and used the tragic mode to describe the collapse of families or the dilapidation of old homes. Therefore, characters in Hawthorne usually face "uncanny [unheimlish]" straits. The concept of "home" has already drawn enough attention from scholars in that it is not only about the "home" itself, but they also link "home" to the development of American society, the philosophy of space and the character of early Americans ${ }^{1}$. Arnold Weinstein even treated Hawthorne' s works as the true beginning of homeless in American literature ${ }^{2}$.

The discussion of the sense of homeless is mainly based on the Heidegger' s discussions about the concept of "uncanniness [Unheimlichkeit]" and " not-at-home [Unzuhause]", and combine them with other relative theories, in order to analyse the sense of homeless more precisely and roundly. "Uncanniness", as one of the key concepts in Heidegger' s theory pedigree, had been mentioned several times in Heidegger' $\mathrm{s}$ work such as The Concept of the History of Time, Being and Time, Introduction to Metaphysics, Hölderlin's Hymn "The Ister" and "Building Dwelling Thinking”. However, to under- stand "homeless" in Hawthorne's works more precisely, we need to understand its close link with the condition of "without-home[Unheimisch]": Hawthorne' s characters often lack their dwelling of reliable family, so they usually stay in a state of "uncanniness" in the world they live in. On the other hand, "homeless" has not been treated as an absolutely passive status in Hawthorne's works. Instead, individuals can deepen their understanding of themselves through fleeing from their home and their family, and get rid of the restrictions of their own family and their house. Therefore, the sense of homeless under Hawthorne' s works always stays in a contradictory binary relations: on the one hand, those citizens need to depend on their clans or households in order to subsist in the society, or they will face the doom like the heroine in The Hollow of the Three Hills. On the other hand, living in a "canny [heimlich]"3 condition for too long will make people indulge in the everyday life, and will make people fall into corruption.

The complexity of "home" in Hawthorne's works originated from both Hawthorne' s dissatisfy with his own clan and the character of early Americans. Hawthorne did not get the cognition of his ancestors in his early years. He even "never really knew his father" before he was four years old, and has been "raised by his mother and sisters, who apparently doted on him"(Bendixen, 2010,p.51). Meanwhile, since he changed his name from "Hathorne" to "Hawthorne", he 
obviously intended to break from his own clan. Another aspect, the patriarchy in early America, is also worth consideration. Even though the North American colonies inherited the hierarchical structures and the contract system from Europe, the patriarchy was still the strongest bond between Europe, more precisely, between the king, with North America, and the relationship between individuals and communities was also depended on " the power of patriarch and the supervise from communities"(Nash, 2018, p.85). Therefore, the evolution of North America from the New England to be independent, can also be taken as the the history of fight against their clans and their "Old Homes"4. Therefore, "homeless" cannot only be treated as people's departure from their home, but also should be taken as a complex ideological system.

\section{WAKEFIELD AND GOLDTHWAITE: THE TWO DIMENSIONS OF "HOMELESS"}

Wakefield and Peter Goldwaite are two characters in Hawthorne's Wakefield and Peter Goldthwaite's Treasure in the same period ${ }^{5}$. Though both of them took the relation between the main characters and their home as the theme, they represented two different manifestations of "homeless": the former one emphasized human's fleeing from home, while the latter paid more attention to people's destruction of their own house. Therefore, they can represent two dimensions of "homeless": the one of human's fleeing from their familiar surroundings and the one of human's destruction of their "ground [grund]".

Wakefield tells the story that the fabled character Wakefield is weary of his daily life after marriage and intends to leave away from his family, so he flees from his home and later returns to his home suddenly at one night. During these twenty years, Wakefield always conceits that someone has been monitoring him, feels afraid of the collapse of his project, and never gets rid of the affect of daily routine which has been cultivated before he left his home. Therefore, with the growing of his ages, he has always been obsessed with the intention to go back home, due to which he has always taken his old house as his " the dwelling which he still calls his own"(Hawthorne,1987,p.297). At the beginning of the story, the writer has already told us that the reason why Wakefield left his home is that he was "in the meridian of life" and "sobered into a calm, habitual sentiment"(Hawthorne,1987,p.291), so he intended to flee from the canny condition and enter the unfamiliar environment, to speculate daily life from the angle of a bystander, in order to gain diverse experience which is different from his daily life before. This intention has been "stirring up"(Hawthorne,1987,p.294) for a moment, and forced him to take actions. However, after he left his home, the world around him begins to show its uncertainty. In the meantime, he is usually trapped by some uncanny things, including "delayed by the throng", the "footsteps... treated behind on him" and "heard a voice shouting afar"(Hawthorne,1987,p.292), and the equivocal fate of his wife also makes him "excited to something like energy of feeling"(Hawthorne,1987,p.295).

These unexpected feelings which hasten Wakefield to leave his familiar surroundings and evoke the passionate emotion in his mind can be seen as the concept of "anxiety [angst]" in Heidegger's theory. "Anxiety" is a kind of feeling that "hits us when suddenly it dawns on us"(Dahlstrom,2013,p.15), the inducement of which is totally different from those which can lead to "fear [Furcht]", so it is much close to those vague things and scenes I mentioned in the prragraph above. These things can be taken as "nothingness [Nichts]", which are "nothing that takes place in the world, nothing definite, nothing worldly"(Heidegger,1985,p.290). In the meantime, anxiety does not purely come from the affection of the outside world, because "this physiological possibility itself exists only because this entity, which is corporeally determined, can by virtue of its being be in dread at all, and not because some physiological occurrence could produce something like dread"(Heidegger,1985,p.290). That is why a man indulged in a canny status cannot experience anxiety without entering an environment which is filled with uncanniness. Wakefield, therefore, chooses to leave the environment of his everyday life, which means to get rid of the canny environment and state of mind, so as to seek for anxiety initiatively and transform the sense of homeless into the sense of "uncanny". It is due to his await to gain the experience of anxiety that Wakefield chooses to extricate himself from the monotonous life and enter another vaster and abundant world, which is different from the world of his everyday life.

Nevertheless, Wakefield is not able to get rid of the canny status drastically at the end of the novel, which can be tracked to the "nostalgia" accompanied with him from the beginning of the novel. Nostalgia has been put forward by Johannes Hofer, which aimed at analyzing the phenomenon that soldiers who stayed in Low Countries missed their motherland, and a serious of physical symptoms accompanied with this kind of yearning. According to researches of Alex Davis and Donald Beecher, similar sensibilities have shown in the work of Medieval Romance, Renaissance Romance and Spencer's poems ${ }^{6}$. What's more, James G.Hart also tried to distinguish nostalgia from the notion of "homesickness". In his point of view, the most distinctive difference between these two concepts is that the former one can be "cured", so long as people "go back home, and the pain will go away"(Hart,1973,p.399). Nevertheless, the latter one, "homesickness", not only sets us away from home, but also represents a "a reverie of the past"(Hart,1973,p.402) from the dimension of time, thus makes people fall into the condition of "daydream"(Hart,1973,p.408), in Hawthorne' s own word, a state of "haunted mind". Though the thought of nostalgia does not that practical, it will linger in people's mind, which may fit well with Beecher' s discussion of the Renaissance Romance. Based on his discussion, one of the core issues of the Renaissance Romance is its hallucinatory memory of the chivalry age, that composed a prevalent inclination of nostalgia among Renaissance Romance writers. Moreover, according to Huizinga's description, the phenomenon of nostalgia was also widespread during Middle Ages. Since "the essence of chivalry is the imitation of the ideal hero"(Huizinga,1990,p.37), people usually conceal them self deliberately under " fanciful brilliance of the heroism and probity of a past age"(Huizinga,1990,p.35), hence formed a 
universal illusion of the fabled past. Therefore, "nostalgia" may not be treated as a personal problem. Instead, it should be taken as a kind of suffused and pervaded retrospective feeling, which extends in the dimension of space and time. Hawthorne, undoubtedly, was deeply infatuated with Romance. He once read James Tomason' s Castle of Indolence and Spencer's The Faerie Queene when he was young. He also once read the work of Don Quixote and The Female Quixote, two of the typical works which contains parody of the feeling of nostalgia about the Middle Ages. Hawthorne also accepted systemic education of Classics in Bowdoin College ${ }^{8}$. Hence, he might borrow the sense of nostalgia both in the dimension of space and time, and to use them in his own works, which can be typically found out from the story of Wakefield.

In Wakefield, the writer intends to remind us of the character of nostalgia owned by Wakefield. From the spacial dimension, Wakefield always wants to return to his old home. His new house is separated from his old house one street away, and he also peeps at his old home and the life of his wife intermittently (but with a high frequency). During those years he left his home, he"haunt[s] around his house"9)(Hawthorne,1987,p.295), which restricts him to the canny status, or, to explain more precisely, a condition of "being-at-home". Similarly, in the dimension of time, Wakefield also cherishes his life with his wife before, as we mentioned earlier, a kind of canny experience which exhausts and wearies him before. During his absense from his home, he has been trapped by an idea that "I shall soon go back"(Hawthorne,1987,p.297) for twenty years. It does not only mean that he wants to go back to his home spacially, but also represents his intention to revise his life into the form of that in the past. For these reasons, the writer calls his home "grave"(Hawthorne,1987,p.298) for the following reason: basing on the haunted feeling nostalgia, Wakefiled is forced to go back to his familiar home and lifestyle before he experiences "anxiety" indeed, but his old home will not accept him, since Wakefield has already dissevered " himself from the world to vanish to give up his place and privileges with living men, without being admitted among the dead"(Hawthorne,1987,p.296), which makes him be doomed to be "not-at-home" in the world.

The blend of escape and nostalgia contained in Wakefield was converted to other forms in Peter Goldthwaite's Treasure. In the novel, "homeless" was manifested as the absence of the "ground" where individuals exist in. At the beginning, Goldthwaite becomes impoverished because of his unsuccessful investment, so he begins to destruct his house prepensely, in order to get those treasures left by his ancestors. But after his destruction of his own house and discovers the "treasure" of his ancestors, he finds out that those treasures are merely a pile of useless tatters, or more precisely, "old provincial bills of credit, and treasury notes, and bills of land-banks, and all other bubbles of the sort, from the first issue, above a century and a half ago, down nearly to the Revolution"(Hawthorne,1987,p.540-541). During this phase, Galdthwaite also experiences the process from "being-at-home", an canny environment, to "homeless". However, different from Wakefield's desire to flee from the canny environment around him, Galdthwaite was once infatuated with the honor of his family mightily, a pattern of manifestation nostalgia as we discussed above (see page four), and obsessed with the canny environment in his house. He once cut "the initials of his name.in the wooden doorpost"(Hawthorne,1987,p.527), and during the process of demolition of his house, he has "long absented himself from his former lounging-places"(Hawthorne,1987,p.530), and stays in his house all through ${ }^{10}$. Meanwhile, the honor of his family, also attracts Galdthwaite' s infatuation. Not only did he miss the contributions of the ancestors in the Revolution, but he even imagined "former Peter Goldthwaite had come back"(Hawthorne, 1987,p.528) when he watched the mirror, but it is another haunted experience, and does not make Galdthwaite experience "anxiety". On the contrary, he treats it as the encouragement from his ancestors. Therefore, Galdthwaite's destruction of his house has become more short-sighted and absurd, because during this procedure, he has always treated his house as useful object, which is equal to the treasures and property in the secular affairs, and finally lures him to throw away the tradition and honor of his family that used to be the bedrock of his existence before. And the maid of his house, Tabitha, also holds the same opinion, or even more pragmatic than Galdthwaite, that she can use the timber of the house to "make a fire"(Hawthorne,1987,p.527).

Because of Galthwaite's ignorance of the experience of anxiety, he destructs his ground ultimately. After he has begins to destruct his house, he found out a protrait of demon, and digged out a cave just behind the wall. These things could have arouse the feeling of anxiety in Galdthwaite and prevented him from devastating his home, if Galthwaite had had the tension to seek for the feeling of "uncanniness" in his life and get rid of his indulge in everyday life (here, "everyday life" should be taken as his pursuing of the treasures). Consequently, this overlook of the anxiety finally leads to the demolishment of his ground: house once existed before finally became "castles in the air"(Hawthorne,1987,p.522), which had been foreseen at the beginning of the novel, and this big house, once full of furniture, finally becomes "nothing but a shell,the apparition of a house", and finally "dissolved in smoke"(Hawthorne,1987,p.537), made Galdthwaite fall into the homeless condition. But it is still reasonable for us the imagine that since John Brown gives him a bunch of money at the end of the novel, in order to buy the fancied house of Galdthwaite, the homeless condition will never be changed in the future. Therefore, he will ultimately indulge in the canny status, and finally fall into the similar condition like Wakefield.

\section{SENSE OF "HOMELESS": THE STATUS OF "CORRUPTION" AND "SOLITUDE" OF INDIVIDUALS}

Wakefield and Galdthwaite provide two different dimensions of the universal status of homeless in Hawthorne' $s$ works. Some characters, for instance, the heroine in the The Hollow of the Three Hills, was under the condition of "notat-home" at the beginning of the story, while some other characters such as Reuben in Roger Malvin's Burial, once owned their own homes, but finally wrecks them on their 
own hand. These characters, like Wakefield, are expelled from their canny environment and wander in the uncanny world without any personal aims. Since their roam does not depend on their own will, they are not only experiencing "uncanniness" in the world, but are also easily be attempted by those objects, especially artificial products such as the buildings and merchandises in shops. The Adam and Eve in The New Adam and Eve should be taken as a typical example. At the beginning of the story, they have already been set in this strange world under the status of "thrownness [Geworfenheit]". This kind of strangeness has originated from their status of homeless: Adam and Eve left from their home and enter into the secular world. In other words, the reason why Adam and Eve wander in the world is totally based on their departure from their canny environment, Eden, and their sense of homeless in the world. Meanwhile, along with their wandering around the city, they are attracted by the new world, and forget the fact that they have been thrown into the technical world without others and full of tempatation, and begin to indulge in this new world.

The wandering process in The New Adam and Eve should be treated as the unescapable consequence of the universal consequence of the sense of homeless: ordinary people, $\mathrm{Pu}-$ ritans and mythical characters will necessarily experience the process from their "corruption" in their religious life to their solitude in their "secular" life, and finally fall into the predicament of "groundless [Abgrund]". This predicament can be seen as the burning of classic volumes in Earth's Holocaust, and people's scraping of ancient canons in The Celestial Rail-Road ${ }^{11}$. In the latter work, those canons with classic ideas have been judged from the angle of utilitarian. Therefore, since these works are "unsubstantial stuff"(Hawthorne,1987,p.808) without any pragmatic usage, all of these canons, including "some editions of books of morality, volumes of French philosophy and German rationalism, tracts, sermons, and essays of modern clergymen, extracts from Plato, Confucius, and various Hindoo sages, together with a few ingenious commentaries upon texts of Scripture"(Hawthorne,1987,p.809), have been thrown into the mud under the footbridge, and the only outcome of this action is that people are more likely to be tempted by demon, which is revealed at the end of the novel. In these two novels, "usefulness [Nützlichkeit]" is the only standard used by people to evaluate thought. At the same time, human has been put into the center of the world, and these thoughts became sheer objects outside human, making people only pay attention to their usefulness in the secular world where people live in. The religious corruption and the division of the world can be traced to the narrate of dividing the world of totality into several heterogenous parts. The narrator of this work often realizes that he stays "in a certain edifice", but this house is the the center of the "the world of fancy"(Hawthorne,1987,p.734). It has both dome and Gothic style, which means it lacks the certainty in its form. Here, the certain world is mixed with the uncertainty in the world. Once people walk into the fantasy hall, they are coerced to be split from their former world, "the commercial world"(Hawthorne,1987,p.735), and then cut off their connection with the ground of their life. Therefore, at the end of the novel, the writer announces that " the solid earth has come to an untimely end"(Hawthorne,1987,p.745). Since the heterogenicity of earth has already eliminated the entity of our world, people are sheerly split from the ground they depend on.From this angle, The Hall of Fantasy, Earth's Holocaust and The Celestial RailRoad can be seen as a serious of works with inner relations, the former one represents the diversion between the fantastic world and the real world, while the latter two works describe people's destruction of their ground through their own actions.

The corruption brought by the sense of "homeless" in Hawthorne's work not only makes people fall into the predicament of "not-at-home" corporeally, but will result in people's alienation from their group spiritually, and finally turn into solitude men. This process should be seen as one of the core themes of Young Goodman Brown. What should be mentioned first is that, Hawthorne' s solitude characters are closely related to Hawthorne's personal life experience. Hawthorne was incompatible with the group around him, because "his solitude is partly based on his nature.it is his natural life state"(Gorman,2015,p.37). Therefore, he was wild about isolating "his characters, the compile some scenes to confine their life background"(Gorman,2015, p.102). In Young Goodman Brown, the religious life scenes are confined rigorously. The ancestors of those civilians in the Salem town once took part in the religious persecution, and lacked the dissents in religious groups. As can be seen in the story, these civilians live in the same group and believe in the same religion and corrupted as a collective community. Brown himself also faces the alienation from his group, and deviated himself from the group as an outcast. This phenomenon of alienation forms the deviation from the system of "the small-town life"(Bell,1978, p.55) as has been mentioned by Daniel Bell. From his point of view, the early spirit of American was represented by two different routes and two different persons, the "Puritan temper"- "Highbrow" by Jonathan Edwards, and the "Protestant ethic"- "Lowbrow" by Benjamin Franklin(Bell,1978, p.56). These two different dimensions of the American's characters have been fused in the Salem Town in the novel. This little town seems to be people's familiar home, but at the same time, it also recalls people's collective memory of the horrible past: the Salem Witch Craft, and even persistently summons this historical stage to the present. In the novel, the same group of people can both teach other people the "catechism", much resemble the "sermon" in The Celestial Rail-Road, or take part in the meeting of "ecclesiastical council"(Hawthorne,1987,p.282), but they are also participants of the "council-board of the province". Therefore, Brown's departure from the town means his alienation from both his own family, which represents the secular life of people, and from the religious group, which symbolizes people's religious life. Both the family and the religious group can be understood as people's everyday life, or, an environment in which people can be call "at-home [zuhause]", leading to civilians' corruption in their religious life. Therefore, Brown's alienation from his "home" is much like seeking for the feeling of uncanniness, in order to find another way of living different from those indulged people. 
The track of Brown's action in the novel can be regarded as the process of leaving home, experiencing the feeling of anxiety and becoming a man of solitude. Brown walks out of his home "after crossing the threshold"(Hawthorne,1987,p.276), then walks into the "haunted forest"(Hawthorne,1987,p.284), then watches the Christian mysteries ritual after the guide of a man with black cloak, witnesses the corruption of his wife, and finally loses his faith in the group he lives in. The man with black cloak, much like the Mr. Smooth-it-away in The Celestial Rail-Road, can be understood as the incarnation of demon, who kept trying to mislead Brown and make him indulge in the world of corruption. During this course of events, the "haunted forest" plays an important intermediary role in the alienation of Brown and his experiencing of the uncanniness, since after Brown's leaving away from his home, the whole story happens in this haunted forest. Those scenes and plots happened in the forest, including "snakelike staff "(Hawthorne,1987,p.279), the switch of the devotional believers to the witch, the horrified sight of mysteries ritual, the pink ribbon "fluttered lightly down through the air"(Hawthorne,1987,p.283), etc., can be both the uncanny surroundings for Brown, and the projection of his disbelief of the piety of those Puritans. In this novel, Hawthorne deliberately created a scene without entity. Since many scenes in the novel are reflected by the sight of Brown under the guidance of the demon, these scenes cannot be judged as real events that once happened or the consequence of Brown's imagination. The forest is haunted because of the fact that Brawn was leaded by the man in the black cloak and forced to leave his conversant environment. The concept of "haunt" is closely related to "anxiety", because "Uncanny experiences are haunting experiences.uncanny experiences are usually frightening.all manner of phantom doubles conjure up.desires for dead things to come alive, a haunting experience "(Gordon,2004, p.243). Brown's haunting experience is different from the pure experience of "ghost"12 in that the latter one is dominated by the influence from objects to the subjective experience, which was shown as the guidence from ghost, the mysterious environment and the mysterious ritual in the novel. Things mentioned above can only invoke a kind of "being afraid of something" instead of a real "anxiety"(Heidegger,1985, p.283), because "the sense of being 'not-at-home' or 'unhomely' arises from within the very idea of the home and the familiar as its internal necessity of identity's other, rather than being that which is supposedly external, a binary opposition and, therefore, an identity in its own right"(Wolfreys,2004, p.240). Therefore, the seeking of the sense of anxiety is largely based on people's awareness of the fact that the sense of uncanniness is based on their everyday life and their aspiration to flee from this living condition. The analysis of Wolfreys is much tally with Tzvetan Todorov's differentiation between "The Marvelous [le nerveilleux]" and "The Uncanny [1' etrange]"13, especially his analysis of The Turn Of The Screw.

Throughout the whole novel, Brown's sense of anxiety mainly comes from his personal choice, it is not only represented in his thought that "my journey...must needs be done 'twixt now and sunrise"(Hawthorne,1987,p.276), but also be represented in his choosing of taking actions in order to seek for the truth, even when he is under the suppress of the haunted environment in the forest. These actions, including escaping from the old lady who once taught him before, looking for Faith who has already been judged to death by the demon, and alienating himself for the corrupted group, largely crumble Brown's familiar living environment. Those faithful believers finally follow the pace of the devil and become the "covert"(Hawthorne,1987,p.286) of Satan. At the end of the novel, Brown falls into "gloom"(Hawthorne,1987,p.289), a kind of "self-alienation", since he finally becomes a man who "loses individual integrity and independence and becomes a stranger to oneself "(Bunnin, 2004, p.22), which reveals the essence of the sense of anxiety. It is because of the confusion of the real life and the illusion from the haunted forest that Brown loses his believe in his own judgement. Therefore, there is nothing left in Brown's life except the experience of the uncanniness in both religious and secular life, and finally make him a solitude individual.

The character of solitude men accompanied with the sense of homeless is the epitome of the the fate of individual Puritans in Hawthorne's early writings. Since during the early ages of the development of the American Puritanism, the relationship between individuals and collectives has always been the central problem of both secular and religious life. This tendency is related to the idea of the early Puritanism. Before the birth of the Puritanism, Calvinism has already paid attention to "mediate the self-discipline and the social control"(Nash,2018, p.78), while, William Perkins, the early Puritanism theologist, once thought that " the issue of the conscience [of Puritans], in fact, is one the the three basic issues: the relation between oneself and the God, the relation of oneself and others, and the issue which only relates to individuals"(Van Til,2011, p.20). As can be seen from their research, Calvinism and early Puritanism both emphasize on the mediation of the relationship between individuals and collectives. However, Puritanism in the North America colonies has been exhibited as the transformation of the power and right of individuals to their collectives. Those male citizens who signed the Mayflower Compact "admit to elect leaders from themselves and follow the authority of the latter"(Nash,2018, p.80). Winthrop was obsessed with building the "City Upon a Hill"(Nash,2018, p.84), and insisted that "the concern of communities should overstep all those personal appeals"(Van Til,2011, p.64), and "the concern of the public advantages should surpass the personal interests"(Van Til,2011, p.66). This is one of the most notable divergences between him and Anne Hutchinson. Meanwhile, after The Great Awakening, the generation of the admonishment in the form of group finally made individuals the objects of the enlightenment in communities. Therefore, the real Puritans were destined to separate themselves from the religious groups or family, if they did want to insist on their original belief of the early Puritanism. In other words, they needed to leave the condition of their indulgence in the collective rule in their religious life, in order to divide themselves with those believers who dedicated themselves to maintaining the authority of the group. Characters like Brown, Hutchinson and the minister with black veil, they are both the renegade in their religious groups, and are people who 
once experienced the sense of uncanniness. They flee from their group under their own resolution, and turn into solitude individuals. On the other hand, some Puritans convert to the instruction of Satan, and people finally indulge in everyday life. These people not only corrupted in their religious life, but also broke the basement of our world, and finally left a pervasive sense of "homeless" to us, and tempted more people to indulge in the corruption and the groundless world.

\section{RAMBLE: A POSITIVE VALIDATION OF SENSE OF "HOMELESS"}

We have already discussed the sense of homeless brought by individuals' fleeing from home. It also leads to another concept in Hawthorne's early short novels: the "ramble"14. The rambling condition surpasses the simplified dualism relation between individuals and the sense of homeless mentioned at the beginning of this article. During the process of ramble, people flee from the "canny environment" they once lived in, and then recognize the responsibility they should take in the world. Through looking at the "haunted" world actively and explore this world, people will fall into a status in which people will gain both familiarity and strangeness of this"haunted" world. Therefore, they will finally understand their own position in the world, and then get rid of the status of the "enslavement" between themselves, the world and others. By understanding themselves and their relation with the world, people can alleviate themselves from the bondage provided by the world they live in, or from "The People [Das Man]" around them, and finally go back to their real home. Different with Hawthorne's critics of "home" in his later works such as The Snow-Image, The House of Seven Gables, and The Blithedale Romance ${ }^{15}$, there was more tension contained in his early works, including Wakefield, Little Annie's Ramble, and his non-fictional work The Whole History of Grandfather's Chair. In these works, Hawthorne both cherished and rejected different representations of "home", including people's houses, their motherland and their family.

Little Annie's Ramble can be taken as Hawthorne's attempt to seek an active dimension, which I call the"rambling condition", for the prevailed sense of homeless in people's daily life. The novel talks about the rambling story of the narrator and Annie. The story begins with Annie' leaving away from her home and ends up with Annie's going back to her home. Meanwhile, the narrator also left and finally goes back into the group of people, or, what we mentioned before, he finally goes beck into "The People". According to Daniel O. Dahlstrom's opinion, "The People" and "Authenticity [Eigentlichkeit]" should always be taken as a couple of paradoxical relation, and the intermedia among this group of relation is "anxiety", since it can make people get away from the immersion in "The People"16. Specifically, in Little Annie's Ramble, this escape from "The People" is shown in the scene in which the narrator and Annie left away from the group of people.

The narrator told us at the beginning of the story that Annie chooses to leave her home and goes to ramble because she "is weary of this wide and pleasant street"(Hawthorne,1987,p.228). The reason brings us back into the theme of getting rid of the "canny environment" as we discussed before. For those ramblers in Hawthorne's work, the world is far from what Heidegger called "un-hiddenness [das Entbergen]", which was used by him to explain the ancient Greek word "Aletheia". For ancient Greeks, "Aletheia was something very different from truth"(Kelley,1998, p.10). Heidegger's explanation about the relationship of "hiddenness" and "unhiddenness" contained in the concept of "Aletheia" corresponds to the transformation of the epistemology in $19^{\text {th }}$ America. During this era, scholars and writers such as Emerson, Thoreau and Hawthorne began to criticize Hume's empiricism and transformed to the epistemology of transcendentalism and mysticism ${ }^{17}$. Therefore, those ramblers do not treat the world as an object in order to speculate and analyse it and create the empirical cognition on the world. By contrast, they try to extract themselves from the phenomenon of the world they live in, and then try to enter the "essence" of their world through walking "into a free relationship with that which concerns us from its essence"(Heidegger,1993, p.313). Therefore, they can both understand their condition of "not-at-home" as well as their close relation to the world. Thereafter, Hawthorne emphasized the horrible running cars after Annie left her home, while Annie passed these cars "with fearless confidence"(Hawthorne,1987,p.229), but those "throng of grown people" around her "make way for"(Hawthorne,1987,p.229) her automatically. Because of this, Annie was split away from "The People" around her who feel indifferent about their world. Meanwhile, they also lack the "anxiety" about their everyday life and the fearful urban view. What is most ironical is that people immerse in the fearful view of their everyday life, but they originate the feeling of "being afraid of something" when they face the little Annie who destroys this view of daily life. Hence, they want to leave away from her, while little Annie "appears conscious of her claim to such respect"(Hawthorne,1987,p.229), which means she does not have the feeling of fear.

We have already discussed the difference between "being afraid of something" and "anxiety" that stays in the things lead to them. Those sense lead by haunted things should be taken as "anxiety" instead of "being afraid (fear) of something". Therefore, we need to understand the difference between these two feelings before we analyse the difference between the feeling of "being-at-home" and "homeless". The sense of "fear [Fürcht]" always comes from "something threatening within-theworld, something that approaches us from a certain direction with the potential to harm us in a determinate way"(Dahlstrom,2013, p.16), which means that "fear of something" always accompanied with certainty, and this kind of certainty is always something "we encounter and confront in a worldly way"(Heidegger,1985, p.285) and "something detrimental"(Heidegger,1985, p.286). When little Annie left those crowds from the other side of the street, she helps the narrator get rid of the condition of the immersion in "The People", so as to break up the immersion status of the group of "The People" around them. Therefore, these adults do not respect little Annie indeed. In fact, they fear those ramblers who left home. This kind of fear originates from the fact that ramblers' rambles break the familiar order of people's everyday life and force "The People" to alienate 
themselves from the environment. Therefore, these people's action of not standing in Annie's way also suggests their aspiration to stay in the condition of immersion in the everyday life.

Therefore, little Annie does not fall into the condition of "groundlessness and nullity of inauthentic everydayness" in a "downward plunge [Absturz]"(Heidegger,1985, p.223) way, but choose to leave the familiarity of "being-at-home". Hence, ramblers will not always stay in the fettle of "not-athome", but will always be curious about everything, which makes the world always be inexperienced to them, and help them to unveil their site in the world. On the one hand, homeless ramblers enter the status of "uncanniness" but on the other hand, they are calling for the recognition of the world. Ramblers do not select parts of the world as their cognitive object, but divide their cognition process into two different parts. One is to walk into the world actively, while another is to wait for the strange things "spring out", one of the features of Altheia, on their own. In Little Annie's Ramble, everything appears along with Annie and narrator's ramble, but those two ramblers do not decide the things they browse and the order of their ramble. On the contrary, they wait for these things "bringing-forth [Her-vor-bringen]"(Heidegger,1993, p.317) to themselves during their ramble.

It is because of this difference in the recognition process that makes the world seems different among ramblers and those non-ramblers. Those non-ramblers hold the opinion that the world is full of confusion and can be very "noisy", so the "quiet people"(Hawthorne,1987,p.233) cannot be heard in the world. In the meantime, those adults are lifeless, many of them "have leaden feet"(Hawthorne,1987,p.229), or even like a squirrel who has already been "condemned to the treadmill but still "makes it an amusement"(Hawthorne,1987,p.232). The contradiction between ramblers and non-ramblers is represented most evidently in the follow description:

Good bye, Dame Doll! A toy yourself, you look forth from your window upon many ladies that are also toys, though they walk and speak, and upon a crowd in pursuit of toys, though they wear grave visages. Oh, with your neverclosing eyes, had you but an intellect to moralize on all that flits before them, what a wise doll would you be(Hawthorne, 1987,p.231)!

People become the subject as well as the objection of the observation activity. In non-rambler's society, people fall into the prevailed status of "materialization". Even though they can still be treated as active individuals, their action can only be thought as mechanical actions like a doll, an artificial product. So they can only recognize the artificial product instead of discover the nature itself. They can only see things remain in "disclosedness [Erschlossenheit]" instead of realize the "emerge [Aufgehen]" of things, because of the fact that in the world of non-ramblers, " insofar as humans are oblivious to the fact that every disclosedness involves concealment, they fall into the illusion of thinking that nothing is hidden and that everything is totally out front"(Guignon,1993, p.19). On the contrary, the two ramblers in the story always keep curious about the shops they saw during their ramble. They do not categorize these shops through their pragmatic usages. Therefore, they never immerse in enjoying products in these shops or trapped by these shops. Instead, they treat these shops and merchandises as a media of their imagination, so as to trigger the imagination of the inexperienced world. Yet for those people who immerse in everyday world, these shops are only taken as a usable place, in which they can consume merchandises and enjoy the artificial products, and forfeit their ability of imagination. Thus, only narrator and Annie can realize the emerge of the nature in their technical world and keep themselves out of this seductive world. The concept of "home" begins to differentiate into two categories. For non-ramblers, "home" is an entirety grouped by "The People" who can provide shelter for them, in which people can seek for safety and familiarity, and they will immerse in this entirety forever. By contrast, ramblers want to flee from this entirety, and then make the world become more "canny", and then experience the feeling of "anxiety" or "uncanniness" in this addictive "home".

Therefore, rambling can be seen can be seen as the active dimension of the pervasive sense of homeless in people's daily life: little Aie leaves her home for her own will, and finally goes back to her home; the narrator endures the tempatation of the world, and finally chooses to "return into the crowd. to struggle onward and do our part in life"(Hawthorne,1987,p.235), and get rid of the immersion in the shelter provided by "The People".Hence, ramblers finally find their own position and their way of being in the world, and split their destiny from others'. Anthony Vidler once distinguished two different kinds of "uncanny": the one that belongs to people's hoe and their house (the personal realm), and the one that belongs to the city (the realm of communities $)^{18}$. Two ramblers in the novel are set under the the status of "uncanniness", and practice rambling through the "uncanny world" in both the narrow and the broad sense. They both understand that they will finally go back to their home and go back to the group of "The People" in the narrow sense of uncanny. In like manner, they refute the tempatation of everyday life and prevent themselves from being immersed in the technical and consumer world. According to rambling, the ramblers find their own "home" in the world at both physical and mental level, found the new ground of their life, and gain the ability to stay away from corruption and wandering in this world.

\section{CONCLUSION}

This article begins with the logical starting point of the sense of "homeless" in Hawthorne's works and analyzes two dimensions of the generation of "homeless". It then discusses the corruption and alienation of individuals in communities and religious groups. This article also focuses on "ramble" in Hawthorne's works and the positive dimension of the sense of "homeless". Through rambling, people can prevent themselves from immersion in the shelter provided by "The People" around them, and can also get rid of the temptation of the artificial world. The condition of "homeless" cannot be merely understood as an experience of those exact things, but also contains the tension between certainty and vague- 
ness of the world. It cannot be triggered by those entities, but it is usually accompanied with those "haunted" images and scenes. The sense of homeless can make people become the solitude individuals, but can also make people leave from their familiar environment and experience "anxiety". Thus, individuals can exist in the world in a refreshed way and retrieve the ground they depend on, and free themselves from the shadow of "The People". Meanwhile, Hawthorne's cogitation of the sense of homeless also gets rid of the mechanical binary opposition between time and space. It can be expressed as the eclipse of a house, family, and clan, and become a prevailed nostalgia with the feeling of emptiness after the disappearance of the past time.

\section{END NOTES}

1. 1Cf. Jackson, Holly. American Blood: The Ends Of The Family In American Literature, 1850-1900. Oxford:Oxford Univ Press,2014\&Klimasmith, Betsy. At Home in the City: Urban Domesticity in American Literature and Culture,

1850-1930.University of New Hampshire Press,2005. About the conversion of the relationship the the public and private life, cf. Sonnet, Richard.The Fall of Public Man.London: Pegion, 2002

2. Cf. Weinstein, Arnold. Nobody's home : speech, self, and place in American fiction from Hawthorne to DeLillo. Oxford: Oxford Univ. Press, 1993

3. Here, the word "canny" has to meanings, according to Heidegger' s analysis, "familiar" and "at home". We will understand the round connotation of the word "uncanny" only if we take both these two meanings into consideration. Therefore, I use the phrase "canny environment" with the meaning of "familiar surroundings".

4. Here, I use the title of Hawthorne' s sketch "Our Old Home" in order to emphasize Hawthorne' s own consciousness of the relation between motherland and home.

5. The former one was published in 1835 and included in the Twice Told Tales, vol.1, when the latter was published in 1838 and included in the Twice Told Tales, vol.2.

6. cf. eecher, Donald.Nostalgia and the Renaissance Romance.Philosophy and Literature, Volume 34, Number 2, October 2010, pp. 281-301; Davis,Alex.Coming Home Again: Johannes Hofer, Edmund Spenser, and Premodern Nostalgia.Parergon, Volume 33, Number 2, 2016, pp. 17-38

7. This is the title of Hawthorne' s short work Haunted Mind, which was published in 1835 and included in Twice Told Tales, vol. 2. We will discuss it in the fourth part.

8. The discussion above is mainly based on Stewart, Randall.Nathaniel Hawthorne, a Biography. New Haven: Yale Univ. Press, 1949

9. Here, haunt is also a key concept relates to uncanniness, which will be discussed in the next part.

10. Here, the word "lounging-places" fits well with our discussion of the concept "canny", for it can provide us a kind of familiarity of one place in our mind, and makes us indulge in it, which is typically represented in the New Adam and Eve.

11. The former one was published in 1844 , and the latter one was published in 1843, The Hall of Fantasy in the paragraph below was published in 1842, all these three works were collected in Mosses From Old Manse.

12. Cf. Bennett,Andrew.An Introduction to Literature, Criticism and Theory. London:Routledge,2014:160-168

13. Cf. Todorov, Tzvetan. Trans. Howard, Richard. The Fantastic: A Structural Approach to a Literary Genre. New York: Cornell University Press, 1975, chapter three, "the uncanny and the marvelous"

14. The following discussion mainly focused on Little Annie's Ramble, which was published in 1835, and collected in Twice Told Tales, vol.2.

15. About the critics of the "home" in The Snow-Image, cf. Mastroianni, Dominic.Politics and Skepticism in Antebellum American Literature.Cambridge: Cambridge Univ. Press,2014:107-118;

About the opposition of the urban home in The Blithedale Romance, cf. Amore, Maura.De.Hawthorne and the Suburban Romance.Studies in American Fiction, Volume 37, Issue 2, Fall 2010:155-180

16. Cf. Dahlstrom, Daniel O. Heidegger dictionary.London:Bloomsbury Press,2013:208. I will discussion about this opinion further in the following paragraphs.

17. To read more about the emphasis on the "secret" advocated mainly by Emerson, cf. Mastroianni, Dominic. Politics and Skepticism in Antebellum American Literature, especially its introduction.

18. Cf. Masschelein, Anneleen. The Concept as Ghost: Conceptualization of the Uncanny in Late-Twentieth-Century Theory. Mosaic: An Interdisciplinary Critical Journal, Vol. 35, No. 1:53-68

\section{REFERENCE}

Bendixen, Alfred. (2010). A Companion to the American Short Story.Sussex: Blackwell Publishing

Bell, Daniel.(1978). The Cultural Contradictions of Capitalism.NY: Basic Books, Inc.,Publishers

Bennett,Andrew.(2014.)An Introduction to Literature, Criticism and Theory. London: Routledge

Dahlstrom, Daniel O. (2013).Heidegger dictionary.London: Bloomsbury Press

Guignon,Charles B. ed.(1993). The Cambridge companion to Heidegger.Cambridge: Cambridge Univ. Press

Gorman, Herbert Sherman.(2015). Hawthorne: A Study in Solitude. Wu Han: Wu Han Univ. Press

Hawthorne, Nathaniel.(1987). Tales and Sketches.NY: Literary Classics of the United States

Hart,James G.(1973). Toward a phenomenology of nostalgia. Man and World, Vol.6(4), pp.397-420

Heidegger, Martin. Trans. Kisiel, Theodore.(1985).History of the Concept of Time: Prolegomena. Bloomington: Indiana Univ. Press

Heidegger, Martin. Trans Macquarrie,John \&Robinson, Edward.(1985).Being and Time. Oxford: Basil Blackwell Publisher 
Heidegger, Martin.(1993).The Question Concerning Technology, in Krell, David Farre. Ed. Basic writings. San Francisco: Harper Press

Huizinga, John. Trans Hopman, F. (1987). The Waning of The Middle Ages. New York: Pegion

Julian,Wolfreys.(2004).Critical Keywords in Literary and cultural Theory.New York: Palgrave Macmillan

Kelley, Donald R.(1998). Faces of history: historical inquiry from Herodotus to Herder. New Haven \&London: Yale University Press

Masschelein, Anneleen.The Concept as Ghost: Conceptualization of the Uncanny in Late-Twentieth-Century Theory.

Mosaic: An Interdisciplinary Critical Journal, Vol. 35, No. 1:53-68
Nash Gary B.(2018).The American People: Creating a Nation and a Society. Beijing: Beijing Univ. Press

Schalow,Frank\&Denker,Alfred.(2010).Historical dictionary of Heidegger's philosophy.Maryland: Scarecrow Press

Stewart, Randall.(1945).Nathaniel Hawthorne, a Biography. New Haven: Yale Univ. Press

Todorov, Tzvetan. Trans. Howard, Richard.(1975). The Fantastic: A Structural Approach to a Literary Genre. New York: Cornell University Press

Van Til, L. John.(2011). Liberty of Conscience: The History of a Puritan Idea. Gui Zhou: Gui Zhou Univ. Press

Weinstein, Arnold.(1993). Nobody's home: speech, self, and place in American fiction from Hawthorne to DeLillo. Oxford: Oxford Univ. Press 